DOI https://doi.org/10.30525/978-9934-26-182-4-19

\title{
EVALUATION OF THE ANXIETY LEVEL IN YOUNG PEOPLE WITH POST-CONCUSSION SYNDROME
}

\author{
Tovazhnyanska O. L. \\ Doctor of Medical Sciences, Professor, \\ Head of the Department of neurology \\ Kharkiv National Medical University \\ Riznychenko O. $\mathbf{K}$. \\ Candidate of Medical Sciences, \\ Assistant Professor at the Department of neurology \\ Kharkiv National Medical University \\ Kharkiv, Ukraine
}

Background: traumatic brain injury (TBI) is a common cause of death and disability among young people of working age. According to statistics, mild traumatic brain injury (mTBI) accounts for $60-95 \%$ of all TBI [1, pp. 42-47; 2, p. 45]. According to the classification, the mTBI includes concussion [3, pp. 32-35; 4, pp. 437-444]. The causes of concussion are road accidents, domestic, sports, industrial and criminal injuries. After the acute and subacute phases of concussion, post-concussion syndrome sometimes occurs, the manifestation of which is most often autonomic dysfunction (AD), one of the symptoms of which is anxiety [5, pp. 191-198; 6, pp. 12-21; 7, pp. 83-93; 8, pp.86-88].

Objective: to evaluate the level of anxiety (personal and reactive) as a manifestation of autonomic dysfunction in young people with postconcussion syndrome.

Methods: we examined 84 patients with post-concussion syndrome, 63 males and 21 females. The average age was 24.5 years. Among the causes of TBI, domestic trauma predominated. All patients were tested with the StateTrait Anxiety Inventory (STAI). This is the only method that allows to differentially measure anxiety as a personal property and as a condition associated with the current situation. [9, pp. 136-138].

Results: changes in the level of anxiety (personal and reactive) were found in all patients who took part in the study. At the same time, increased indicators of personal anxiety were recorded to an average of 36 points, and in people with panic attacks - up to 42 points. 
Conclusions: therefore, the STAI demonstrated increased indicators of anxiety as manifestations of autonomic dysfunction among patients who suffered a mild traumatic brain injury accompanied by post-traumatic concussion syndrome.

\section{References:}

1. Раимкулова К.Б. Особенности легкой черепно-мозговой травмы (обзор литературы). Вестник КазНМУ. 2014. № 2 (1). С. 42-47.

2. Шевага В.Н. Ранние и отдаленные последствия черепно-мозговой травмы: медико-социальные аспекты и возможности нейропротекции. Здоровье Украиныл. 2009. № 5/1. С. 45

3. Победенный А.Л. Распространенность и структура черепномозговой травмы в крупном промышленном регионе. Украӥнський нейрохірургічний журнал. 2011. № 3. С. 32-35.

4. Stein S. C., Spettell C. The Head Injury Severity Scale (HISS): a practical classification of closed-head injury. Brain injury. 1995. Vol. 9, № 5. P. 437-444.

5. Vos P.E. Mild traumatic brain injury. European Journal of Neurology. 2012. № 19. P. 191-198.

6. Лихтерман Л.Б., Кравчук А.Д., Филатова М.М. Сотрясение головного мозга: тактика лечения и исходы. Анализы клинической $и$ экспериментальной неврологии. 2008. Т.2. № 1. С. 12 -21.

7. Григорова I.А., Некрасова Н.О. Психосоматичні розлади й адаптивна реабілітація хвоих у віддаленому періоді закритої черепномозкової травми. Врачебная практика. 2001. № 6. С. 83-93.

8. Школьник В.М., Фесенко Г.Д. Прогнозирование риска пролонгации инвалидности в отдаленном периоде черепно-мозговой травмы. Международный медицинский журнал. 2017. № 2. С. 86-88.

9. Вейн А.М., Вознесенская Т.Г., Воробьева О.В. Вегетативные расстройства (клиника, лечение, диагностика). Москва, 2000. С. 752. 